BEduManageRs Journal

Borneo Educational Management and Research Journal, Vol.2, No.1, 2021

ISSN: 2747-0504

\title{
Optimalisasi Pelayanan Dan Motivasi Kerja Dengan Kedisiplinan Pegawai Dalam Mengukur Kepuasan Kinerja
}

\author{
Amir $^{1}$, M. Jafar Haruna ${ }^{2}$, Mursalim ${ }^{3}$ \\ Universitas Mulawarman \\ e-mail: doktormp@fkip.unmul.ac.id
}

\begin{abstract}
The Influence Sevice Optiamisation and Job Motivation with Employee Dicipliner in Measure Job Satisfaction Toward Administration Power at UPT and Education Official East Kutai Regency Provincy East Kalimantan.

There is research to aim for the service optimalisation effect and employee motivation with employee dicipliner in measure work satisfaction toward administration power at UPT and Education Official East Kutai Rigrncy. There is kausal study do it Eighteen District and twenty UPT between one Education Official East Kutai Regency. The method used in this Research is Quantitative method with multiple Regression Analisis. The Sample of this research is one hundred and two respondent of four hundred fifty nine at Population. The result of this research is that there is a significant positive influence either partially or colletively between the effect service optimalisation and work motivation with employee dicipliner to measure work satisfaction employees toward administration power at UPT and Education Official East Kutai Regency.

Based on the results of this study the researcher concludes that the batter of service optimalisation and work motivation with employee to dicipliner to result in more the more feeling satisfaction in the job.(1), The Higght more the more in motivation work or duty do it to result in of satisfaction the work (2), The Dicipline more the more and rule obdient employee doing the duty or manner rule, more the more to hoist satisfaction work (3), More the more service optimalisation, more the more work motivation with more the more rule obdient employees in dicipline their work becoming satisfaction to gether the administration power, more the more to services.
\end{abstract}

Keywords: The Services Optimalisation and work Motivation with dicipliner Administration Power in measure of Satisfaction.

\section{PENDAHULUAN}

Perkembangan zamanyang semakin maju pada dekade 2010 menuntut adanya Sumber Daya Manusia (SDM) yang berkualitas. SDM yangberkualitas merupakan modal utama untuk mencapai tujuan pembangunan. Salah satu wahana untuk meningkatkan kualitas SDM tersebut adalah pendidikan. Undang-undang Nomor 20 Tahun 2003 tentang Sistem Pendidikan Nasional Bab I Pasal 1 Ayat 1 menyatakan pendidikan adalah usaha sadar dan terencana untuk mewujudkan suasana belajar dan proses pembelajaran agar peserta didik secara aktif mengembangkan potensi dirinya untuk memiliki kekuatan spiritual keagamaan, pengendalian diri, kepribadian, kecerdasan, akhlak mulia, serta keterampilan yang diperlukan dirinya, masyarakat, bangsa dan negara. Sistem pendidikan nasional merupakan keseluruhan komponen pendidikan yang saling terkait secara terpadu untuk mencapai tujuan pendidikan nasional. Salah satu komponen dalam pendidikan nasional yaitu tenaga 
BEduManageRs Journal

Borneo Educational Management and Research Journal, Vol.2, No.1, 2021

ISSN: 2747-0504

kependidikan yang bertugas melaksanankan administrasi, pengelolaan, pengembangan, pengawasan, dan pelayanan teknis untuk menunjang proses pendidikan pada satuan pendidikan.

Tenaga kependidikan berkewajiban untuk membantu menciptakan suasana pendidikan yang bermakna, menyenangkan, kreatif, dinamisdan dialogis dan harus menjadi teladan dan menjaga nama baik lembaga, profesidan kedudukan sesuai dengan kepercayaan yang diberikan oleh masyarakat untuk menjadi bagian yang terpenting dalam proses penyelenggaraan pendidikan. Kualitas tenaga kependidikan merupakan kemampuan tenaga kependidikan untuk mengoptimalkan kinerjanya agar menghasilkan layanan yang optimal pada pelaksanaan pendidikan. Kualitas pendidikan di Indonesia saat ini sangat memprihatinkan. Ini dibuktikan antara lain dengan data UNESCO tahun 2009 tentang peringkat Indeks Pengembangan Manusia atau Human Development Index, yaitu komposisi dari peringkat pencapaian pendidikan, kesehatan, dan penghasilan perkapita yang menunjukkan bahwa indeks pengembangan manusia Indonesia makin menurun. Diantara 174 negara di dunia, Indonesia menempati urutan ke-111 tahun 2007 dari sebelumnya ke-109 pada tahun 1999, terjadi penurunan peringkat. Hal tersebut menunjukan kualitas sumber daya manusia Indonesia terpuruk.

Menurut Survey Political and Economic Risk Consultant (PERC), kualitas pendidikan di Indonesia berada pada urutan ke-12 dari 12 negara di Asia. Posisi Indonesia berada dibawah Vietnam. Data yang dilaporkan The World Economic Forum Swedia (2000), Indonesia memiliki daya saing yang rendah, yaitu hanya menduduki urutan ke-37 dari 57 negara yang disurvey di dunia. Dan masih menurut survey dari lembaga yang sama Indonesia hanya berpredikat sebagai follower bukan sebagai pemimpin teknologi dari 57 negara di dunia.

Memasuki abad ke- 21 dunia pendidikan di Indonesia menjadi heboh. Kehebohan tersebut bukan disebabkan oleh kehebatan mutu Pendidikan Nasional tetapi lebih banyak disebabkan karena kesadaran akan bahaya keterbelakangan pendidikan di Indonesia. Hal ini disebabkan karena beberapa hal yang mendasar. Salah satunya adalah memasuki abad ke- 21 gelombang globalisasi dirasakan kuat dan terbuka. Kemajuan teknologi dan perubahan yang terjadi memberikan kesadaran baru bahwa Indonesia tidak lagiberdiri sendiri. Indonesia berada di tengah-tengah dunia yang baru, dunia terbuka sehingga orang bebas membandingkan kehidupan dengan negara lain. Yang kita rasakan sekarang adalah adanya ketertinggalan didalam mutu pendidikan. Baik pendidikan formal maupun informal. Hasil itu diperoleh setelah kita membandingkannya dengan negara lain. Pendidikan memang telah menjadi penopang dalam meningkatkan sumber daya manusia Indonesia untuk pembangunan bangsa. Oleh karena itu, kita seharusnya dapat meningkatkan sumber daya manusia Indonesia yang tidak kalah bersaing dengan sumberdaya manusia di negara-negara lain.

Didata lain berdasarkan kesimpulan yang dilaporkan oleh Bank Dunia dalam World Development Report 2002 menyatakan bahwa layanan publik di Indonesia masih sangat

rendah. Hasil penelitian Governance and Desentralization Survey (GDS) 2002 menemukan tiga masalah penting yang banyak terjadi di lapangan dalam penyelenggaraan pelayanan publik, yaitu pertama, besarnya diskriminasi pelayanan. Optimalisasi pelayanan publik oleh birokrasi pemerintahan bukanlah pekerjaan mudah, mengingat optimalisasi menyangkut berbagai aspek yang telah membudaya dalam lingkaran birokrasi pemerintahan.

Salah satu aspek tersebut adalah kultur birokrasi yang tidak kondusif. Permasalahan utama pelayanan publik pada dasarnya berkaitan dengan peningkatan kualitas pelayanan itu sendiri. Pelayanan yang berkualitas sangat tergantung pada berbagai aspek, yaitu bagaimana pola penyelenggaraannya (Tata Laksana), dukungan sumberdaya manusia, dan kelembagaan serta adanya konsep yang jelas. Prosedurdan etika pelayanan yang berkembang dalam birokrasi 
BEduManageRs Journal

Borneo Educational Management and Research Journal, Vol.2, No.1, 2021

ISSN: 2747-0504

pemerintah sangat jauh dari nilai-nilai dan praktik yang menghargai warga bangsa sebagai warga negara yang berdaulat. Prosedur pelayanan, misalnya, tidak dibuat untuk mempermudah pelayanan, tetapi lebih untuk melakukan kontrol terhadap perilaku warga, sehingga prosedurnya berbelit-belit dan rumit.

Indonesia merupakan sebuah bangsa yang besar. Pembangunan nasional yang dilakukan oleh bangsa Indonesia adalah pembangunan manusia seutuhnya yang bertujuan untuk mewujudkan suatu masyarakat yang adil dan makmur berdasarkan Pancasila dan UndangUndang Dasar 1945. Pembangunan yang berlangsung sampai saat ini tidak hanya melakukan pembangunan secara fisik semata, tetapi juga non fisik yang berupa peningkatan kualitas sumber daya manusia. Dalam persaingan global saat ini, dunia kerja sangat membutuhkan orang yang bisa berfikir untuk maju, cerdas, inovatif dan mampu berkarya dengan semangat yang tinggi dalam menghadapi era globalisasi saat ini. Adanya persaingan di berbagai sektor yang membuat proses pengelolaan, dan pemeliharaan manajemen organisasI semakin mendapatkan perhatian yang serius dari seluruh elemen yang ada dalam sebuah organisasi. Sumber daya manusia yang dalam hal ini adalah para pegawai pada sebuah lembaga/organisasi, tentunyaberusaha bekerja dengan kemampuan yang mereka miliki agar dapat mencapai kepuasan kinerja yang diinginkan. Kepuasan kinerja pegawai harus diciptakan sebaikbaiknya supaya moral kerja, dedikasi,kecintaan, dan kedisiplinan pegawai meningkat. Kepuasan kinerja adalah sikap emosional yang menyenangkan dan mencintai pekerjaannya. Sikap ini dicerminkan oleh moral kerja, kedisiplinan, dan prestasi kerja. Kepuasan kinerja dinikmati dalam pekerjaan, luar pekerjaan, dan kombinasi dalam dan luar pekerjaan (Malayu, 2000, hal : 199). Telah dimaklumi bahwa produktivitas suatu organisasi dipengaruhi oleh banyak faktor, seperti kesempatan memperoleh pendidikan dan pelatihan tambahan, penilaianprestasi kerja yang adil, rasional dan objektif, sistem imbalan dan berbagai faktor lainnya. Motivasi dan kepuasan kinerja merupakan bagian dari berbagai faktor tersebut. Akan tetapi dilihat dari sudut pemeliharaan hubungan dengan para karyawan, motivasi dan kepuasan kinerja merupakan bagian yang penting,karena dengan motivasi ini diharapkan setiap individu pegawai mau bekerja keras dan antusias untuk mencapai produktivitas yang tinggi. Motivasi mempersoalkan bagaimana caranya mengarahkan daya dan potensi bawahan, agar mereka mau bekerja sama secara produktif berhasil mencapai dan mewujudkan tujuan yang telah ditentukan. Setiap kegiatan yang dilakukan seseorang tidak terlepas dari berbagai motif (daya dorong) dan sikap, yang mendorong seseorang tersebut melakukan serangkaian yang disebut kegiatan. Daya dorong yang berasal dari diri seseorang untuk berbuat sesuatu ini disebut motivasi. Tanpa motif orang tidak akan berbuat sesuatu. Itulah sebabnya mengapa motif perlu dibahas dan ditumbuhkan agar supaya dapat menjadi pendorong perbuatan yang positif sesuai dengan apa yang dikehendaki oleh organisasi. Motif dapat timbul dari dalam karena ada kebutuhan dasar manusia yang bersifat universal, tetapi dapatpula diransang dari luar. Ransangan dari luar dapatberbentuk fisik atau nonfisik disebut motivasi. Meskipun ada motif lalu berbuat, namun belum menjamin bahwaperbuatan itu akanmenghasilkan sesuatu yang dikehendaki. Sebagai penjamin, paling tidak sebagai pembantu agar perbuatan itu dapat menghasilkan sesuatu yang diinginkan dalam kondisi baik, perlu disertai sikap dan tingkah laku yang dibawakan oleh orang yang bersangkutan. Sikap yang mendasari tingkahlakuseseorang akan memberi warna terhadap perbuatan itu, sehingga pihak-pihak yang menerima hasil perbuatan(dalam hal ini pihak yang menerima pelayanan) akan merasa puas dan mempunyai kesan baik terhadap cara pelayanan yang diberikan. Hal ini berdampak positif terhadap organisasi dan para pelaku pelayanan pada organisasi itu. Sehingga merubah minsed menjadi perangkat terbaik pada layanan.

Di sisi lain, dalam pelayanan umum terdapat beberapa faktor pendukung yang penting, diantaranya faktor aturan yang menjadi landasan kerja pelayanan. Aturan 
BEduManageRs Journal

Borneo Educational Management and Research Journal, Vol.2, No.1, 2021

ISSN: 2747-0504

merupakan perangkat penting dalam segala tindakan dan perbuatan orang. Dalam Organisasi kerja aturandibuat oleh manajemen sebagai pihak yang berwenang mengatur segala sesuatu yang ada di Organisasi kerja tersebut. Oleh karena itu berbagaiaturan/norma yang ditetapkan oleh suatu lembaga memiliki peran yang sangat penting dalam menciptakan kedisiplinanagar para pegawai dapatmematuhi dan melaksanakanperaturan tersebut (Ulfah M, 2011). Salah satu syarat agar dapat ditumbuhkan kedisiplinan dalam lingkungan kerja ialah adanya pembagian pekerjaan yang tuntas sampai kepada pegawai atau petugas yang paling bawah, sehingga setiaporang tahu dengan sadar apatugasnya, bagaimana

melakukan, kapan pekerjaan dimulai dan kapan selesai, seperti apa hasil kerja yang disyaratkan, dan kepada siapa ia mempertanggungjawabkan hasil pekerjaan itu. Salah satu kelemahan yang ada pada kita yang sering tidak disadari dan hakikatnya sangat merugikan, baik bagi penyelenggara kegiatan maupun bagi masyarakat yang menerima pelayanan ialah, kita mampu mencipta (termasuk disini aturan) tetapi kita sangat lemah dalam memelihara ciptaan kita itu. Akibatnya jelas aturan sebagai hasil ciptaan itu tidak lagi memenuhi fungsi semula, tidak/kurang bermanfaat, bahkan dapat merugikan pihak-pihak yang seharusnya memperolah pelayanan denganbaik. Salah satu bentuk pemeliharaan aturan ialah kedisiplinan dalam pelaksanaansecara tertib dan konsisten. Melalui disiplin yang tinggi pelaksanaan suatu aturan dapat mencapai maksud dan dapat dirasakan manfaatnya oleh semua pihak, dengan ketentuan bahwa aturan itu dibuat setelah mempertimbangkan asas keadilan dan kemanfaatan bagi kepentingan umum Berdasarkan penelitian yang dilakukan oleh Rohmalia (2014) menunjukkan bahwa : (1) Motivasi berpengaruh positif dan signifikat terhadap kepuasan kinerja, (2) Motivasi kerja berpengaruh positif dan signifikan terhadap kinerja gur (3) Disiplin kerja berpengaruh positif dan signifikan terhadap kepuasan kinerja, (4) Disiplin kerja berpengaruh positif dan signifikan terhadap kinerja guru (5) Kepuasan kinerjaberpengaruh positif terhadap kinerja guru.
Sedangkan penelitian yang dilakukan oleh Abidin Nur (2010) menunjukkan bahwa Kepuasan Kinerja tidak berpengaruh signifikan terhadap Kedisiplinan Kerja pegawai, Motivasi Kerja tidak berpengaruh signifikan terhadap Kedisiplinan Kerja, Kepuasan Kinerja tidak berpengaruh signifikan terhadap Kinerja Pegawai, Motivasi Kerja berpengaruh signifikan terhadap Kinerja, dan Kedisiplinan Kerja berpengaruh signifikan terhadap Kinerja Pegawai.

\section{KAJIAN TEORI}

Kepuasan kinerja tenaga kependidikan adalah suatu bentukperasaan seseorangyang mendapatkan pengalaman kinerja (atau hasil) yang telah memenuhi harapannya, yang meliputi (Assauri, 2003): 1) Waktu yang digunakan untuk menunggu dilayani. 2) Kecepatan dan ketepatan dalam Pelayanan kepada mahasiswa. 3) Ketepatan dalam melaksanakan dan menepati janji. 4) Keramahan dan kesopanan pimpinan dan karyawan dalam bersikap dan berbicara. 5) Pengetahuan pimpinan dan karyawan dalam pelayanan. 6) Prosedur dalam pelayanan dan penyelesaian layanan. 7) Kemudahan pimpinan dan karyawan untuk dihubungi. 8) Tempat pelayanan nyaman, bersih bagi tenaga kependidikan 9)Menciptakan kelancarandalam pelayanan. 10) Keramahan pelayanan berpengaruh terhadap kepuasan kinerja tenaga kependidikan.

Menurut Kotler (2007), kepuasan pelanggan adalah tingkat perasaan seseorang setelah membandingkan kinerja (atau hasil) yang ia rasakan dibandingkan dengan harapannya. Salah satu cara dalam mengukur sikap pelanggan adalah dengan menggunakan kuesioner/skala rating. Perusahaan harus mendesain kuesioner/skala rating kepuasan pelanggan yang secara akurat dapat memperkirakan persepsi pelanggan tentang kualitas barang atau jasa. Newstrom mengemukakan bahwa, "Job satisfaction is the favorableness or unfavorableness with employes view their work." Kepuasan kinerja berarti perasaan mendukung atau tidak mendukung yang dialami karyawan (Karyawan dari kata dasar "Karya" berarti 
BEduManageRs Journal

Borneo Educational Management and Research Journal, Vol.2, No.1, 2021

ISSN: 2747-0504

pekerja, sering kali disebuah pabrik atau Kantor besar. Oleh Pemerintah Orde Baru, kata ini digunakan untuk menggantikan istilah buruh yang sejak 1965 ditabukan di Indonesia).

\section{Definisi Motivasi}

Motivasi adalah aktivitas perilaku yang bekerja dalam usaha memenuhi kebutuhan-kebutuhan yang diinginkan. Untuk memahami lebih dalam definisi motivasi berikut beberapa pendapat paraahli tentang motivasi. Chung \& Meggison menyatakan bahwa "Motivation is defined as/goal-directed behavior. It concerns the level of effort one excerts in pursuing a goal ... It is closely performance (Motivasi dirumuskan sebagai perilaku yang ditujukan pada sasaran. Motivasi berkaitan dengan tingkat usaha yang dilakukan oleh seseorang dalam mengejar suatu tujuan. motivasi berkaitan erat dengan kepuasan dan performa pekerjaan).

\section{Definisi Kedisiplinan}

Menurut Simamora (1997)Disiplin adalah prosedur yang mengoreksi atau menghukum bawahan karena melanggar peraturan atau prosedur. Disiplin kerja adalah suatu alat yang digunakan para manajer untuk berkomunikasi dengan karyawan agar mereka bersedia untuk mengubah suatu perilaku serta sebagai suatu upaya untuk meningkatkan kesadaran dan kesediaan seseorang menaati semua peraturan perusahaan dan norma-norma sosial yang berlaku.

Hasibuann (2004) berpendapat bahwa kedisiplinan adalah kesadaran dan kesediaan seseorang menaati semua peraturan perusahaan dan norma-norma sosial yang berlaku.

\section{METODE PENELITIAN}

Penelitian ini merupakan penelitian asosiatif kausal dengan menggunakan pendekatan kuantitatif. Penelitian asosiatif kausal adalah penelitian yang bertujuan untuk mengetahui pengaruh antara dua variabel atau lebih. Penelitian ini menjelaskan hubungan mempengaruhi dan dipengaruhi dari variabelvariabel yang akan diteliti. Menggunakan pendekatan kuantitatif karena data yang akan digunakan untuk menganalisis hubungan antar variabel dinyatakan dengan angka atau skala numerik. Penelitian ini menganalisis pengaruh Optimalisasi Pelayanan, dan motivasi kerja dengan Kedisiplinan Pegawai dalammengukur Kepuasan Kinerja terhadap tenaga Kependidikann di UPT dan Dinas Pendidikan Kutai Timur. Pengujian hipotesis penelitian dilakukan penghitungan data-data kuesioner yang telah disebarkan di lapangan pada responden. Regresi dilakukan untuk menguji hubungan antar Variabel, diantaranya harus memenuhi persyaratan bahwa VariabelVariabel tersebut mempunyai hubungan yang linier, selain untuk menguji linieritas antara Variabel-Variabel penelitian dan untuk mengetahui berapa besar pengaruh Variabel bebas $\mathrm{X} 1, \mathrm{X} 2$, dan $\mathrm{X} 3$ terhadap Variabel terikat Y. Untuk mengetahui pengaruh antara variabelpenelitian tersebut digunakan teknik analisis dengan bantuan program komputer SPSS for Windows versi 16,0 .

\section{HASIL DAN PEMBAHASAN}

1) Pengaruh Langsung Positif Optimalisasi Pelayanan, Motivasi Kerja, Dan Kedisiplinan Pegawai Terhadap Kepuasan Kinerja (X1，X2，X3 Terhadap Y)\

Hipotesis yang akan diuji adalah :

$H_{0} .: \beta 1=\beta 2=\beta 3=0$

$H_{1} .: \beta \mathrm{j} \neq 0$, Untuk paling kecilsatu dari $\mathrm{j} . \mathrm{j}$

$=1,2,3$ Menggunakan Taraf Signifikan

0.05 , dengan uji $\mathrm{F}$

Berdasarkan hasil perhitungan diperoleh nilai sig. $=0,000$ yang artinya lebih kecil dari nilai $\alpha=0,05$. Oleh karen taraf signifikansi statistik $\mathrm{F}$ kurang dari taraf signifikan pengujian yaitu $0,000<$ 0,05 maka Ho ditolak. Ini berarti ada koefisien yang tidak sama dengan nol. Sehingga disimpulkan bahwa ada Variabel bebas (Optimalisasi Pelayanan, Motivasi Kerja, dan Kedisiplinan) yang signifikan berpengaruh terhadap Kepuasan Kinerja. 
BEduManageRs Journal

Borneo Educational Management and Research Journal, Vol.2, No.1, 2021

ISSN: 2747-0504

\section{2) Pengaruh Langsung Positif OptimalisasiPelayanan Terhadap Kepuasan Kinerja (X1)}

Hipotesis yang akan diujiadalah :

$$
\begin{aligned}
& H_{0} .: \beta 1 \quad=0 \\
& H_{1}:: \beta 1 \neq 0
\end{aligned}
$$

Berdasarkan hasil perhitungan diperoleh nilai sig. $=0,003$ yang artinya lebih kecil dari nilai $\alpha=0,05$. Untuk mengetahui signifikan tidaknya Optimalisasi Pelayanan berpengaruh positif terhadap kepuasan kerja dilakukan uji hipotesis. Hasil perhitungan diperoleh $\mathrm{t}$ hitung $=$ 3,011 sedangkan $\mathrm{t}$ tabel $=1,659$ pada $\mathrm{dk}=$ $3 / 102$ dan $\alpha=0,05$, sehingga $t$ hitung $>\mathrm{t}$ tabel atau 3,011 > 1,659.

Berdasarkan hal demikian, hipotesis nol yang diajukan tidak diterima, sedangkan H1 diterima artinya Optimalisasi Pelayanan berpengaruh positif terhadap Kepuasan Kinerja.

\section{3) Pengaruh Langsung Positif Motivasi Kerja Terhadap Kepuasan Kinerja (X2)}

Hipotesis yang akan diujiadalah :

$$
\begin{aligned}
& H_{0} .: \beta 2=0 \\
& H_{1}:: \beta 2 \neq 0
\end{aligned}
$$

Berdasarkan hasil perhitungan diperoleh nilai sig. $=0,000$ yang artinya lebih kecil dari nilai $\alpha=0,05$. Untuk mengetahui signifikan tidaknya Motivasi kerja berpengaruh positif terhadap Kepuasan Kinerja dilakukan uji hipotesis. Hasil perhitungan diperoleh $\mathrm{t}$ hitung $=$ 6,572 sedangkan t tabel $=1,659$ pada $\mathrm{dk}$ $=3 / 102$ dan $\alpha=0,05$, sehingga $\mathrm{t}$ hitung $>\mathrm{t}$ tabel atau 6,572 >1,659.

Berdasarkan hal demikian, hipotesis nol yang diajukan ditolak, sedangkan $\mathrm{H} 1$ diterima artinya Motivasi kerja berpengaruh positif terhadap Kepuasan Kinerja.

\section{4) Pengaruh Langsung Positif Kedisiplinan Pegawai Terhadap Kepuasan Kinerja(X3)}

$$
\begin{aligned}
& \begin{array}{l}
\text { Hipotesis yang akan diuji } \\
\text { adalah: }
\end{array} \\
& H_{0}:: \beta 3=0 \\
& H_{1}:: \beta 3 \neq 0
\end{aligned}
$$

Berdasarkan hasil perhitungan diperoleh nilai sig. $=0,003$ yang artinya lebih kecil dari nilai $\alpha=0,05$. Untuk mengetahui signifikan tidaknya Kedisiplinan pegawai berpengaruh positif terhadap kepuasan kinerja dilakukan uji hipotesis. Hasil perhitungan diperoleh t hitung $=3,098$ sedangkan $\mathrm{t}$ tabel $=1,659$ pada $\mathrm{dk}$

$=3 / 102$ dan $\alpha=0,05$, sehingga $\mathrm{t}$

hitung $>\mathrm{t}$ tabel atau 3,098 >1,659.

Berdasarkan hal demikian,hipotesis nol yang diajukan ditolak, sedangkan $\mathrm{H} 1$ diterima artinya Kedisiplinan Pegawai berpengar positif terhadap Kepuasan Kinerja.

\section{Hubungan PengaruhOptimalisasi Pelayanan Terhadap Kepuasan Kinerja TenagaKependidikan.}

Berdasarkan Hasilpengujian regresi maka didapatkan bahwa terdapat pengaruh Optimalisasi Pelayanan terhadap Kepuasan Kinerja tenaga kependidikan UPT dan Dinas Pendidikan Kutai Timur.

Hal ini disebabkan karena meskipun dari keterampilan dan pengetahuan petugas mampu memberikan pelayanan yang baiktapi jika tidak ditunjang dengan sarana dan prasarana yang tidak memadai maka hasil yang diharapkan akan tidak maksimal.

Hal ini sejalan dengan penelitian Aisyah (2012) tentang Hubungan kualitas pelayanan internal terhadap kepuasan kerja dan kemampuan petugas memberikan pelayanan berkualitas di RSUD Lanto Daeng Pasewang.

Hal ini tidak sejalan dengan keputusan menteri pendayagunaan aparatur Negara NO 63/KEP/M.PAN/7/2013 tentang pedoman umum penyelenggaraan pelayanan publik, bahwa kebijakan ini tidak akan dicapai secara 
BEduManageRs Journal

Borneo Educational Management and Research Journal, Vol.2, No.1, 2021

ISSN: 2747-0504

maksimal apabila aparatur pemerintah tidak berkerja secara optimal, oleh karena itu, kebijakan yang dikeluarkan oleh menteri pendayagunaan aparatur Negara dalam upaya meningkatkan kualitas pelayanan harus di imbangi dengan upaya optimalisasi kinerja aparatur pemerintahdan melakukannya secara konsisten dengan memperhatikan segala kebutuhan dan harapanmasyarakat.

\section{Hubungan Pengaruh Motivasi Kerja Terhadap Kepuasan Kinerja Tenaga Kependidikan.}

Berdasarkan Hasil pengujian regresi diketahui bahwa terdapat pengaruh Motivasi kerja terhadap Kepuasan Kinerja tenaga kependidikan UPT dan Dinas Pendidikan Kutai Timur.

Hal ini sesuai dengan penelitian yang dilakukan oleh Ratna Sari (2016) dengan judul pengaruh motivasi kerja dan kompetensi terhadap kepuasan kerja serta implikasinya pada kinerja pegawai di UPT Puskesmas Sindang Jaya Kota Bandung yakni Dari hasil uji t antara motivasi (X1) terhadap Kepuasan Pegawai (Y) dapat dirumuskan dalam persamaan analisis jalur sebagai berikut : $\mathrm{Y}=0,626 \mathrm{X} 1+0,608$ Persamaan analisis jalur di atas menggambarkan bahwa semakin tinggi motivasi maka kepuasan pegawai akan meningkat pula. Darihasil uji t antara variabel motivasi (X1) terhadap Variabel Kepuasan Pegawai (Y) dengan koefisien jalur sebesar 0,626 , diperoleh $t_{\text {hitung }} 5,438$ lebih besar dari $\mathrm{t}$ tabel 1,684 , dengan taraf signifikansi sebesar 0,05 maka H0 ditolak. Dengan demikian dapat disimpulkan bahwa motivasi berpengaruh terhadap kepuasan pegawai di UPTPuskesmas Sindangjaya sebesar $39,19 \%$ Hal ini sesuai dengan Chun dan Meggison dalam Sulastri (2010 : 90) bahwa: " motivasi dirumuskan sebagai perilaku yang ditunjukan pada sasaran motivasi berkaitan dengan tingkat usaha yang dilakukan seseorang dalam mengejar suatu tujuan. Motivasi berkaitan erat dengan kepuasan pekerjaan dan performance pekerjaan". Motivasi pada dasarnyamerupakan daya dorong yang mampu menggerakkan pegawai sehingga merasa puas dalam bekerja dan mendorong merekabekerja lebih baik. Hal tersebut sesuai dengan Hasibuan (2004) bahwa pemberian motivasi membuat seseorang lebih bersemangat untuk bekerja agar dapat bekerja sama, bekerja secara efektif dan terintegrasi yang bertujuan untuk mendapatkan kepuasan. Selain itu pemberian motivasi kepada pegawai bertujuan untuk mendorong pegawai agar bekerja lebih semangat, meningkatkan kepuasan kerja pegawai, meningkatkan kedisplinan pegawai, menciptakan kondisi dan hubungan kerja yang baik serta meningkatkan rasa tanggung jawabterhadap tugas-tugas yang dikerjakan.

Dalam organisasi motivasi mempunyai peranan penting, karena ia menyangkut langsung pada unsur manusia dalam organisasi dan menjaga keselarasan antara keinginan organisasi dengan keinginan pegawai sebagai pribadi.

Unsur manusia dalam organisasi terdiri dari dua kelompok orang yaitu orang yang memimpin (manajemen) dan orang yang dipimpin (pegawai/pekerja).

Masalah motivasi dalam organisasi menjadi tanggungjawab manajemen untuk mencipta, mengatur, dan melaksanakannya. Oleh karena itu sesuai dengan sifat motivasi yaitu bahwa ia adalah ransangan bagi motif yang mampu menumbuhkan motif orangorang sehingga mau berbuat sesuai dengan kehendak organisasi. Hal ini didukung oleh Handoko (2001) dan Hasibuan (2007) bahwa motivasi para pegawai pada dasarnya bertujuan agar pegawai tersebut merasa puas yang kemudiandiimplementasikan kepada oranglain dalam bentuk pemberian pelayanan yang baik kepada pelanggan. Oleh sebab itu motivasi memiliki peranan yang penting dalam mencapai kepuasan kerja.

\section{Hubungan Pengaruh Kedisiplinan Terhadap Kepuasan Kinerja Tenaga Kependidikan. \\ Berdasarkan hasil pengujian regresi} diketahui bahwa terdapat pengaruh Kedisiplinan terhadapKepuasan Kinerja tenaga kependidikan UPT dan Dinas Pendidikan Kutai Timur.

Hal ini sesuai dengan penelitian yang dilakukan oleh Ahmad Nurul Huda (2017) dengan judul Pengaruh Motivasi Kerja Dan Disiplin Kerja Terhadap Kepuasan Kerja 
BEduManageRs Journal

Borneo Educational Management and Research Journal, Vol.2, No.1, 2021

ISSN: 2747-0504

Karyawan Koperasi Simpan Pinjam Unit Desa Karya Mukti Di Kecamatan Pelepat Ilir Kabupaten Bungo yakni diperoleh koefisien untukvariable disiplin kerja (X2) sebesar 0.517 atau dapat dinyatakan sebagai persamaan linier $\mathrm{Y}=0.517 \quad(\mathrm{X} 2)$. Hasil penelitian tersebut didapatkan nilai $\mathrm{t}$

sebesar 9.142 dengan sig $=0,00$ maka Ho ditolak, dengan kata lain disiplin kerja berpengaruh terhadap kepuasan kerja, ini berarti $\mathrm{H} 2$ diterima. Besarnya konstribusi disiplin kerja terhadap kepuasan kerja diketahui dari Standardized Coeffisien Beta sebesar 51\%. Ini berarti bahwa disiplin kerja memberikan pengaruh terhadap kepuasan kerja sebesar $51 \%$.

Hal ini sejalan Menurut Drs. H. Malayu Hasibuan (2007:193) bahwa Kedisiplinan adalah kesadaran dan kesediaan seseorang menaati semua peraturan perusahaan dan norma-norma sosial yang berlaku. Kedisiplinan harus ditegakkan dalam suatu Organisasi/Instansi. Tanpadukungan disiplin pegawai yang baik, sulit bagi organisasi untuk mewujudkan tujuannya dan kepuasan kinerja pegawai itu sendiri. Jadi,Kedisiplinan adalah kunci keberhasilan suatu Instansi dalam mencapai tujuannya." Disiplin kerja meningkat disebabkan olehkehadiran pegawai yangtepat waktu, tidak pernahpulang sebelum jam kerjaselesai, mampu menyelesaikan pekerjaan tepat waktu, mampu menggunakan waktu secara efektif, bekerja dengan kualitas kerja yang baik, berpenampilan sopan dan berpakaian sesuai aturanyang ada maka dapat menyebabkan kepuasa $\mathrm{n}$ kerja pegawai semakin meningkat. Ketika seseorang merasa puas dalam melaksanakan pekerjaan tentunya ia akan berusaha untuk memaksimalkan kemampuan yang dimiliki dalam menyelesaikan tugasnya.

Dalam memaksimalkan kemampuan serta pekerjaan seseorang, ia akan disiplin atau mentaati peraturan yang telah ditetapkan dalamsuatu organisasi.

\section{Pengaruh Optimalisasi Pelayanan, Motivasi Kerja Dan Kedisiplinan}

\section{Pegawai Terhadap Kepuasan Kinerja \\ Tenaga Kependidikan di UPT dan \\ Dinas Pendidikan Secara Bersama- \\ Sama Saling Mempengaruh dan Hubungannya yang Signifikan.}

Hasil uji hipotesis dengan uji $f$ dan uji $t$ diuraikan bahwa terdapat pengaruh Optimalisasi Pelayanan, Motivasi Kerja dan Kedisiplinan Pegawai terhadap Kepuasan Kinerja secara bersama-sama dan memilki hubungan yangpositif. Oleh karena itu,semakin baik Optimalisasi Pelayanan, semakin bertambah Motivasi Kerja dan Kedisiplinan Pegawaisemakin baik pula kepuasankinerjanya tenaga kependidikan tersebut. Hal ini membuktikan bahwa variabel X1

(Optimalisasi Pelayanan), variabel X2 (Motivasi Kerja), variabel X3 (Kedisiplinan Pegawai), dan variabel $\mathrm{Y}$ (Kepuasan Kinerja) mempunyai arti yang sangat penting dalam mengukur kepuasan kinerja di UPT dan Dinas Pendidikan di KabupatenKutai Timur.

\section{KESIMPULAN}

Berdasarkan analisis hasil penelitian ini dapat disampaikan beberapa temuan sebagai kesimpulan, yang dijabarkan sebagai berikut:

1. Optimalisasi Pelayanan

berpengaruh positif terhadap kepuasan kinerja tenaga kependidikan, artinya pelayanan yang diberikan secara optimal termasuk dalam sarana dan prasarana pelayanan akan meningkatkan kepuasan dalam bekerja. Berdasarkan hasil perhitungan diperoleh nilai sig. $=0,003$ yangartinya lebih kecil dari nilai $\alpha=0,05$. Untuk mengetahui signifikan tidaknya Optimalisasi Pelayanan berpengaruh positif terhadap kepuasan kerja dilakukan uji hipotesis. Hasil perhitungan diperoleh $\mathrm{t}$ hitung $=3,011$ sedangkan $\mathrm{t}$ tabel $=1,659$ pada $\mathrm{dk}=3 / 102$ dan $\alpha=0,05$, sehingga $\mathrm{t}$ hitung $>\mathrm{t}$ tabelatau 3,011 >1,659.

5. Motivasi Kerja berpengaruh langsung positif terhadap kepuasan kinerja tenaga kependidikan, artinya semakin tinggi motivasi 
BEduManageRs Journal

Borneo Educational Management and Research Journal, Vol.2, No.1, 2021

ISSN: 2747-0504

dalam bekerja atau melaksakan tugasnyamaka akan meningkatkan kepuasan dalam bekerja. Berdasarkan hasil perhitungan diperoleh nilai sig. $=0,000$ yangartinya lebih kecil dari nilai $\alpha=0,05$. Untuk menget signifikan tidaknya Mot 138 kerja berpengaruh positif terhadap kepuasan kinerja dilakukan uji hipotesis. Hasil perhitungan diperoleh t hitung $=6,572$ sedangkan $\mathrm{t}$ tabel $=1,659$ pada $\mathrm{dk}=$ $3 / 102$ dan $\alpha=0,05$, sehingga $t$ hitung $>t$ tabel atau $6,572>1,659$.

6. Kedisiplinan Pegawaiberpengaruh langsung posoitif terhadap kepuasan kinerja tenaga kependidikan, artinya semakin disiplin dan semakintaat pegawai dalam

menjalankan aturan yang berlaku pada lingkungan kerja maka semakin meningkat kepuasan dalam bekerja. Berdasarkan hasil perhitungan diperoleh nilai sig. $=0,003$ yang artinya lebih kecil dari nilai $\alpha=0,05$. Untuk mengetahui signifikan tidaknya Kedisiplinan pegawai berpengaruh positif terhadap kepuasan kinerja dilakukan uji hipotesis. Hasil perhitungan diperoleh $\mathrm{t}$ hitung $=3,098$ sedangkan $\mathrm{t}$ tabel $=1,659$ pada $\mathrm{dk}=3 / 102$ dan $\alpha=0,05$, sehingga $\mathrm{t}$ hitung $>\mathrm{t}$ tabel atau 3,098 > 1,659.

7. Optimalisasi Pelayanan (X1), Motivasi Kerja (X2), dan Kedisiplinan Pegawai (X3) berpengaruh langsung positif secara bersamasama terhadap Kepuasan Kinerja (Y) tenaga kependidikan. Artinya semakin Optimal Pelayanan, semakin kuat Motivasi Kerja, dan semakin taat aturan oleh pegawai menjalankan Disiplin Kerja akan semakin meningkatkan Kepuasan Kinerja dalam bekerja tenaga kependidikan tersebut. Berdasarkan hasil perhitungan diperoleh nilai sig. $=0,000$ yang artinya lebih kecil dari nilai $\alpha=0,05$. Oleh karena taraf signifikansi statistik F kurang dari taraf signifikan pengujian yaitu $0,000<0,05$ maka Ho ditolak. Ini berarti ada koefisien yang tidak sama dengan nol. Sehingga disimpulkan bahwa ada variabel bebas (Optimalisasi Pelayanan, Motivasi Kerja, dan Kedisiplinan Pegawai) yang signifikanberpengaruh terhadap KepuasanKinerja.

Berdasarkan hal demikian, hipotesis nol yang diajukan ditolak, sedangkan H1 diterima artinya Optimalisasi Pelayanan, Motivasi Kerja, dan Kedisiplinan Pegawai berpengaruh positif terhadap Kepuasan Kinerja.

\section{DAFTAR PUSTAKA}

Abidin, N."Pengaruh Kepuasan, Motivasi, dan Kedisiplinan Kerja Terhadap Kinerja Pegawai di Lingkungan Kantor Wilayah DepartemenAgama Provinsi JawaTengah." Tesis, Universitas Dian Nuswantoro Semarang,2010.

Admin SPSS Statistik."Uji Linieritas Dengan SPSS Statistik." http://www.spssstatistik. com,2017.(diakses 13 April 2018)

Colquit/LePine/Wesson, Organisational Behavior; Inproving Performance and Commitment in the

Workplace, Mc.Graw-Hill International Edition. The New York,Americans.2009 and Copyright 2011.

Efendra, Gino."PengaruhKepuasan Kerja Terhadap Disiplin Kerja Karyawan Di PT. Bank Rakyat Indonesia Cabang MartadinataKota Bandung”, Skripsi, Universitas Pasuruan,2017. (diakses 20 Januari 2018)

Fahmi, Irham. Manajemen

Kepemimpinan Teori \& Aplikasi. Bandung: Alfabeta, 2014.

Gary Yukl, “ Kepemimpinan Dalam Organisasi, 'State University of New York at Albany, PT. Indeks, Jakarta,2010.

Gering Supriyadi dan Tri Guno. "Budaya Kerja Organisasi Pemerintahan."Lembaga Administrasi Negara-Republik Indonesia Edisi RevisiII, 2003.

Gusti, Messa Media." Pengaruh Kedisiplinan, Motivasi Kerja, Dan Persepsi Guru Tentang Kepemimpinan Kepala Sekolah Terhadap Kinerja Guru SMKN 1 Purworejo Pasca Sertifikasi." Jurnal Penelitian, Universitas Negeri Yogyakarta, 2012. Indrawati, Aniek. "Pengaruh Kualitas Layanan

Lembaga Pendidikan Terhadap Kepuasan Konsumen." Jurnal Ekonomi

Bisnis TH. 16 No.1 (2011), http://fe.um.ac.id/wp-con tent/uploads/2009/10/4-AniekIndrawati.pdf (diakses 30 November 2016). 
BEduManageRs Journal

Borneo Educational Management and Research Journal, Vol.2, No.1, 2021

ISSN: 2747-0504

James R.Evans, "TOTAL QUALITY, Manajemen, Organization, and Strategy.4th Edition, Thomson South Western.Copyright 2005.

Joe Girard, The Word's Greatest Salesman' 13 Aturan Penting Dalam Penjualan. Inilah Caranya Meraih Keberhasilan Dalam Karier dan Bisnis Sekaligus Tampil Menjadi Pribadi Yang Hebat. PT. Gramedia Pustaka Utama, Jakarta: Mei 2016.

Junaidi, Achmad. "Himpunan Aturan KepegawaianSeri 2". Dinas Pendidikan Kabupaten Kutai Timur, 2010.

Kasmaboti. "Pengaruh Gaya Kepemimpinan Kepala Madrasah, Lingkungan, Dan Motivasi Kerja Terhadap Mutu Pelayanan GuruMadrasah Tsanawiyah Negeri Se Kabupaten Kutai Kartanegara. "Disertasi, Universitas NegeriJakarta, 2014.

L.R.Gay,Geoffrey E. Mills, Peter Airasian, 'Educational Research' Competencies for Analysis and Applications, Merritt Is an imprint of PEARSON Upper Saddle River New Jersey Columbus, Ohio.Copyright 2009.

Mahmudi. "Manajemen Kinerja Sektor Publik. Yogyakarta:Unit Penerbit Dan Percetakan STIM YKPN,2015.

Masyjui, Isnan." Pengaruh Motivasi dan Disiplin Kerja Terhadap Kepuasan Kerja Pegawai Kantor Dinas Pendidikan

Nasional Kabupaten Grobongan." Skripsi, Universitas NegeriSemarang, 2005.

Moenir, H.A.S. "Manajemen Pelayanan Umum di Indonesia. Jakarta:BumiAksara, 2000.

M. Amelia dan Drs.Sugiono. "Analisis

Pengaruh Kualitas Pelayanan Terhadap Kepuasan Siswa Dalam Mengikuti Kursus di Lembaga Bimbingan Belajar (Studi Pada Siswa SMA Lembaga Bimbingan Belajar

IPIEMS Cabang BanyumanikSemarang). "Jurnal (2012),http://eprints.undip.ac.id/35628/1/J URNAL_(MIRA_AMELIA_C2A008212) .pdf (diakses 30 November 2016). Nez, Alif Laela. "Upaya Peningkatan Kualitas Tenaga Pendidik dan Kependidikan Melalui Model MBS." Jurnal Seminar
Nasional Evaluasi Pendidikan (2013).

http://journal.unnes.ac.id

/sju/index.php.html (diakses 2 Desember 2016).

Noor, Juliansyah. Penelitian Ilmu Manajemen: Tinjauan Filosofis dan Praktis. Jakarta: Pena Media Group, 2013.

Prawatya, Dipta Adi." Pengaruh Disiplin Kerja Dan Budaya Organisasi Terhadap Kinerja Karyawan Pabrik Minyak Kayu Putih (PMKP) Di Krai Purwodadi." Skripsi, Universitas Diponegoro, 2012.

Priyanto. "Pengaruh Supervisi Kepala Sekolah Budaya Organisasi Dan MotivasiKerja Terhadap DisiplinKerja Guru SMA Negeri Di Kutai Kartanegara. "Disertasi, Universitas NegeriJakarta, 2017.

Ridho, Muhammad Rasid. "CaraMembaca CoefficientsTable

SPSS UntukMembuat Persamaan Regresi." artikel (2015), https://emerer.com (diakses 13 April 2018)

Rahmayanty, Nina. Manajemen Pelayana Prima: Mencegah Pembelotan dan Membangun Customer Loyality. Yogyakarta: Graha Ilmu, 2013.

Ratna, Sari. "Pengaruh Motivasi Kerja Dan Kompetensi Terhadap Kepuasan Kerja Serta Implikasinya Pada Kinerja Pegawai DiUPT Puskesmas

Sindang Jaya Kota Bandung."

Thesis,

Universitas Pasuruan,2017(diakses 20

Januari 2018)

Reza, Regina Aditya. "Pengaruh Gaya Kepemimpinan, Motivasi dan Disiplin Kerja Terhadap Kinerja Karyawan PT. Sinar Sentosa Perkasa Banjarnegara." Skripsi,Universitas DiponegoroSemarang, 2010.

Rohmaliah. "Analisis Pengaruh Motivasi dan Disiplin Kerja Terhadap Kepuasan Kerja Untuk Meningkatkan Kinerja Guru SMP, MTs, dan MA Takhassus Al-Quran Demak." Skripsi,

Universitas DiponegoroSemarang, 2014.

Salim, Nur Agus. "Pengaruh Kemampuan 
BEduManageRs Journal

Borneo Educational Management and Research Journal, Vol.2, No.1, 2021

ISSN: 2747-0504

ManajerialKepala Sekolah,

Kompensasi Finansialdan Non Finansial

Manajemen Konflik, Pengambilan

Keputusan Terhadap Efektivitas

Pengelolaan SekolahDasar(SD) Di

Kabupaten Kutai Kartanegara Provinsi

Kalimantan Timur. "Disertasi,

Universitas Mulawarman, 2017. Saraka.

"Buku Pedoman Penulisan

DisertasiProgramDoktor Universitas

Mulawarman."

Setyaji, Aditya M. "Pelajari Dulu Wajah Pendidikan." PSMKGI.org,

http://psmkgi.org/pelajari

-dulu-wajah-pendidikan/ (diakses 2

Desember2016).

Siti Musdah Mulia, Prof. Dr., MA., APU. "Menuju Politik Perempuan" Upaya Mengakhiri Depolitisasi Perempuan di Indonesia, Kibar Press Sleman Yogyakarta: 2008.

Suharso, Drs. Dan Ana Retnoningsih Dra. "Kamus Besar Bahasa Indonesia" Edisi Lux.Penerbit ; CV. WidyaKarya. Semarang, 2009.

Sudadi. "Pengaruh Kepemimpinan Kepala Sekolah, Kecerdasan Emosional Dan Kepuasan Kerja Terhadap Motivasi KerjaGuru SMP Negeri Di Kecamatan Tenggarong Kabupaten Kutai Kartanegara. "Disertasi, Universitas NegeriJakarta, 2014.

Sukmadinata, Nana Syaodih. "Metode Penelitian Pendidikan Penelitian Memberikan Deskripsi, Eksplanansi, Prediksi, Inovasi, dan Juga DasarDasar Teoritis bagi Pengembangan Pendidikan.

Bandung:Rosda.2012. Sugiyono. "Materi WorkshopInternational Metode Penelitian. 2018."Metode Penelitian Pendidikan Pendekatan Kuantitatif, Kualitatif, dan $R \& D$. Bandung : Alfabeta.2009.

"Metode Penelitian Kombinasi (Mixed Methods).

Bandung:Alfabeta.2017.
"Metode Penelitian Kebijakan Pendekatan Kuantitatif, Kualitatif, Kombunasi $R \& D$ dan Penelitian Evaluasi. Bandung: Alfabeta.2017."Metode Penelitian \& Pengembangan Research and Development.

Bandung:Alfabeta.2015. Sutopo dan Adi Suryanto. Pelayanan Prima "Bahan Ajar Diklat Prajabatan Golongan III Edisi Revisi II”. LembagaAdministrasi Negara,2006.

Taman, Abdullah et al. "Analisis Kualitas Pelayanan Terhadap Kepuasan Mahasiswa Pada Fakultas Ekonomi Universitas Negeri Yogyakarta." Jurnal Nominal Volume.II.(2013),

http://journal.uny.ac.id/index.php/nominal/article /viewFile/1651/1375 (diakses 30 November 2016).

Timpe, A.Dale. "Seri Manajemen Sumber Daya Manusia Memotivasi Pegawai. Jakarta : PT. Alex MediaKomputindo. 2000.

Trihendradi.C. "Step by Step SPSS 20 Analisis Data Statistik. Yogyakarta : Andi Offset.2012.

Ulfa, M. "Pengaruh Motivasi dan Disiplin Kerja Terhadap Kepuasan Kerja Pegawai Kantor Pelayanan Pajak Pratama Medan Kota." Karya Tulis Ilmiah, Universitas Sumatera Utara, 2011.com

Ulwan, M Nashihun. "Cara Membaca atau Melihat Tabel T." 2014.

http://www.portal-statisti k.com. (diakses 13 April2018)

Undang-undang Nomor 20 Tahun 2003 tentang"Sistem Pendidikan Nasional Pasal, Ayat 1.

Wardan, Khusnul. "Motivasi Kerja Guru. "Yogyakarta: Interpena, 2011. Walter R. Borg Meredith D. Gall, " Educational Research An Introduction. "Longman New York \& London. Copyright 1983. 